\title{
DISCURSO PROFERIDO PELO PROFESSOR DOUTOR EROS ROBERTO GRAU NA POSSE DO PROFESSOR HERMES MARCELO HUCK COMO PROFESSOR TITULAR
}

Excelentíssimo Senhor Diretor, D. Congregação, minhas Senhoras, meus Senhores, meu caro Amigo Professor Hermes Marcelo Huck:

Aqui estamos reunidos para cumprir uma tradição. Celebramos o ato público de posse do professor doutor Hermes Marcelo Huck no cargo de professor titular da Faculdade de Direito do Largo de São Francisco.

Que bom - disse-o já em outra ocasião - que bom podermos dizer, com um certo ar de humildade maldisfarçada, que bom podermos dizer, singelamente, se alguém pergunta o que fazemos, que bom podermos dizer, simplesmente: "sou professor no Largo de São Francisco"!

Tenho muito a dizer ao novo professor titular do Largo de São Francisco. É como se, aqui e agora, falassem pela minha voz todos os que nos antecederam na Congregação, além dos que ainda estão entre nós, dizendo da alegria de tê-lo em seu seio.

O professor Hermes Marcelo Huck desde cedo preparou-se para este momento.

Bacharel da turma 1965, já nos anos de 1973 e 1974 freqüentava o curso de pós-graduação de nossa Faculdade, ao qual retornou em 1976, após a obtenção, em 1975, do Master of Laws pela Law School da Universidade da Califórnia, Berkeley. Em 1977 freqüentou curso de Direito Internacional Privado na Academia de Direito Internacional de Haia.

Em 1982 obteve o grau de Doutor em Direito Internacional, com a tese "Contratos com o Estado: aspectos de direito internacional"

Já entre 1976 e 1977, contudo, o professor Hermes Marcelo Huck atuava como docente voluntário, inicialmente, após como auxiliar de ensino do Departamento de Direito Internacional da Faculdade. Em 1978, a contratação como professor assistente.

O professor Hermes Marcelo Huck preparava-se para este momento. Daí o concurso para Livre Docente, em 1991, com a tese "Sentença estrangeira e lex mercatoria. Horizontes e fronteiras do comércio internacional" - publicada pela 
Editora Saraiva - e, após, em 1995, a aprovação em disputado concurso público para o cargo de professor titular de Direito Internacional Público, com a tese "Da guerra justa à guerra econômica. Uma revisão sobre o uso da força em direito internacional", também editada pela Saraiva.

Além dessas teses e do livro organizado em conjunto com os professores Luiz Olavo Baptista e Paulo Borba Casella — "Direito e comércio internacional. Tendências e perspectivas" — em 1994, são inúmeros os artigos e trabalhos didáticos do novo professor titular da Academia de Direito do Largo de São Francisco.

A atividade do professor Huck na Universidade é também extremamente relevante. Vice-Presidente da Comissão de Pós-Graduação de nossa Faculdade entre 1991 e 1994, foi seu presidente no biênio 1996-1998, tendo sido também membro do Conselho de Pós-Graduação e da Comissão de Normas e Recursos da Reitoria de Pós-Graduação da Universidade de São Paulo. Ademais, atua ainda, o professor, como assessor da FAPESP - Fundação de Amparo à Pesquisa do Estado de São Paulo para julgamento de projetos de pesquisa e bolsas de estudo.

Inúmeras vezes, por outro lado, o professor Huck tem participado em bancas de concursos à docência e de mestrado e doutorado, além de ter orientado mestres e doutores e estar, atualmente, a orientar mestrandos e doutorandos.

É muito ampla, também, a atividade do professor doutor Hermes Marcelo Huck como conferencista, no Brasil e no exterior. Visiting Scholar na Harward Law School, em 1981, e em Berkeley, em 1975. Conferências em Seul, Hong Kong, Taipé, Tóquio, Buenos Aires.

Esse, em linhas muito amplas, o perfil do novo professor titular, que ora recepcionamos.

Para tanto aqui estamos, para cumprir uma tradição. E neste momento o meu coração se enche de júbilo, porque desta celebração participo, privilegiadamente, saudando o Professor e o Amigo. Mais de um motivo me traz felicidade, neste momento.

É que sinto como se estivesse a cumprir três papéis, a pronunciar três discursos.

Falam pela minha voz, inicialmente - já o disse - não apenas os colegas da atual Congregação, mas também os que já se foram. 
Professor Hermes Marcelo Huck: os nossos Maiores estendem-lhe as mãos. Vinde a nós - eles dizem — vinde fruir essa imensa alegria de sermos da Academia do Largo de São Francisco, de fazermos parte dela, de sermos de tal modo que sem ela já não somos.

Que bom - repito - que bom podermos dizer, com um certo ar de humildade maldisfarçada, que bom podermos dizer, singelamente, se alguém pergunta o que fazemos, que bom podermos dizer, simplesmente: "sou professor no Largo de São Francisco"!

Há contudo a brotar de mim também um outro discurso. Recebo-o também, professor Huck, como decano do Departamento de Direito Econômico e Financeiro.

Nós o recebemos de braços abertos, mas imediatamente depositando pesada carga em seus ombros.

É que vem com Vossa Excelência também a abertura do Departamento para o Direito Econômico Internacional.

Para tanto Vossa Excelência se preparou. Sua tese sobre evasão e elisão em matéria tributária - com a qual obteve o cargo no qual é agora solenemente empossado - insere-se no entrelaçado de matérias que compõem o quadro de disciplinas jurídicas de nosso Departamento.

A sua presença entre nós enriquece a todos, a cada um, individualmente, ao próprio Departamento e ao Direito Econômico. É como se já tivesse diante de meus olhos o programa, elaborado por Vossa Excelência, da disciplina Direito Econômico Internacional.

Sou portador ainda, todavia, de um terceiro discurso. Permitam-me, minhas senhoras e meus senhores, Douta Congregação, permitam-me uma expansão de afeto.

Agora volto-me ao Amigo. Caminho no tempo, até o início da década dos sessenta.

Essa minha viagem de retorno aos vinte anos é animada - e por isso mesmo se faz fluente - na medida em que diviso, entre nós, agora, alguns rostos da mocidade. Aí estão, Amigo, aí estão o Laerte, o Kalil, o Tofá, o João Renato, o Eduardo Dib, o Itoby...

Nós nos encontrávamos todas as noites - São Paulo era uma cidade bem diferente, calma, tranqüila - encontrávamo-nos na esquina da Barão com a 
Praça da República, durante algum tempo [logo depois de abril de 64] em uma "esquina volante" - por razões óbvias — finalmente na esquina da 24 de Maio.

Era a "Esquina" cujos remanescentes se encontram ainda nas sextasfeiras, à meia-noite, no Gigetto, animados pelos Lima e pelo Belluzzo, às vezes com a minha presença, do Eduardo Kugelmas, do João Renato, do Galvão, do Itoby...

Amigo Hermes: que tempos! Que tempos! Manobrávamos a política universitária... sonhávamos! A política, os livros, os filmes...

Relembro figuras que já se foram: Luciano, Maurício, Barthô, amigos queridos...

Que tempos, Amigo! Pela "Esquina" passavam as escolhas de candidatos para a UEE, DCE's - a eleição do Aluízio para o XI... mesmo a sua, para vice-presidente, na primeira eleição do XI depois do famigerado golpe de $1^{\circ}$ de abril...

Não havia identidade ideológica completa entre todos nós - o tempo nos mostrou - mas éramos universais: gente de fora da área jurídica, da FAU, da POLI, da Veterinária... Laoonte, Raimundo, o Serra, o Laerte...

Não importa, agora, em que eu particularmente não me sinta bem em uma falsa democracia, sob a qual somos governados por medidas provisórias e a Constituição esteja sendo aviltada, vilipendiada. Não importa em que eu me sinta assim - pasmo, ao descobrir que pode haver ditadura mesmo sem repressão e sem prisões! - e esse mesmo sentir não seja compartilhado exatamente na mesma medida por todos. Não, agora não importa...

O que importa mesmo, professor Hermes Marcelo Huck, é que, de repente, o abraço de agora - Você há de vir para este abraço! — é o abraço da Congregação, do Departamento, mas, também o abraço da sua juventude, o abraço da "Esquina"...

São Paulo, junho de 1998. 